\title{
Mechanical cardiorespiratory supports in general thoracic surgeon
}

\author{
Andrea Dell'Amore ${ }^{1}$, Nizar Asadi $^{2}$ \\ ${ }^{1}$ Thoracic Surgery and Lung Transplantation Unit, Department of Cardiothoracic and Vascula Sciences, University of Padua, Padua, Italy; ${ }^{2}$ Division \\ of Thoracic Surgery, The Royal Brompton and Harefield NHS Foundation Trust, Harefield Hospital, London, UK \\ Correspondence to: Prof. Andrea Dell'Amore. Thoracic Surgery and Lung Transplantation Unit, Department of Cardiothoracic and Vascula Sciences, \\ University of Padua, Via Giustiniani 2, Padua 35128, Italy. Email: andrea.dellamore@unipd.it.
}

Received: 02 August 2020; Accepted: 02 September 2020; Published: 25 February 2021.

doi: $10.21037 /$ ccts-2020-mec-06

View this article at: http://dx.doi.org/10.21037/ccts-2020-mec-06

The application of Extra-Corporeal Life Supports (ECLS) has been increasing in the last few years $(1,2)$. Historically, extracorporeal circulation was introduced for the management of severe intraoperative hemorrhagic complications resulting in extremely poor outcomes. However, with further application of these devices in lung transplantation, thoracic surgeons have gained more experience becoming more confidence in the management of extracorporeal circulation especially in Extracorporeal Membrane Oxygenation (ECMO).

It has been confirmed in literature the efficacy of extracorporeal circulation intra-operatively in lung transplantation and challenging airway surgery; this in fact confirmed by its safety due to multiple factors including low-risk of bleeding, minor risk of thrombosis and better biocompatibility for the patient (3).

ECLS include: standard extracorporeal circulation machine, ECMO, pumpless interventional lung assist devices, extracorporeal $\mathrm{CO}_{2}$ removal devices and others $(1,2,4)$.

The use of mechanical cardiorespiratory support generally and more specifically the ECMO, in the last decade, has been gaining more popularity in thoracic surgery; this of course due to the excellent results published by major thoracic surgery centers $(1,2,5)$. Indeed, the intraoperative use of ECMO has become a common practice in complex airway surgery in order to avoid complex ventilation techniques intra-operatively or jet ventilation as well as to facilitate the airway anastomosis with a tubeless surgical technique and ensure better hemodynamic and respiratory stability to patients (5).

Simultaneously, the use of ECLS supports have become a tool widely used in the pre-operative setting for the stabilization of thoracic emergencies such the major thoracic traumas with respiratory failure, severe tracheal stenosis, massive pulmonary embolism, etc. These techniques allow stabilizing the patient and avoiding major complications leading to high rate mortality. Postoperatively, the use of ECMO in different settings has become a common and effective practice in the treatment of Acute Respiratory Distress Syndrome (ARDS) and other diseases such as massive pulmonary embolisms and more recently in the treatment of septic shock patients $(1,2,6-9)$.

Thoracic surgery ECMO supports finding an increase application in the management of post-operative complications following lung resections and in patients undergoing major surgery for neoplastic disease $(1,2,10,11)$. In fact, to date there is no evidence to support that the intra-operative or post-operative use of assisted circulation systems might lead to dissemination of neoplastic cells leading to increased risk of metastasis; hence, extracorporeal circulation has been used and reported in the literature to perform oncological thoracic operations that required resection of the large vessels or part of the cardiac chambers and therefore required cardioplegic arrest or circulatory support during the surgical procedure $(1,2,12)$.

In addition, thoracic surgeons should be an integral part of the multidisciplinary group in the ECMO reference centers for the management of an eventual complications that the supported patients might develop during their hospital stay $(13,14)$.

Therefore, thoracic surgeons nowadays should be trained and develop skills in the management, indications and techniques inherent to the various types of cardio- 
circulatory and respiratory support (15). In summary, these devices definitely should be additional armamentarium in the surgeon hands in order to offer the best outcome and manage different clinical and surgical scenarios and not being limited to only lung transplantation.

\section{Acknowledgments}

Funding: None.

\section{Footnote}

Provenance and Peer Review: This article was commissioned by the editorial office, Current Challenges in Thoracic Surgery, for the series "Mechanical Extracorporeal CardioRespiratory Supports in General Thoracic Surgery". The article did not undergo external peer review.

Conflicts of Interest: Both authors have completed the ICMJE uniform disclosure form (available at https://ccts. amegroups.com/article/view/10.21037/ccts-2020-mec-06/ coif). The series "Mechanical Extracorporeal CardioRespiratory Supports in General Thoracic Surgery" was commissioned by the editorial office without any funding or sponsorship. AD and NA served as the unpaid Guest Editors of the series. The authors have no other conflicts of interest to declare.

Ethical Statement: The authors are accountable for all aspects of the work in ensuring that questions related to the accuracy or integrity of any part of the work are appropriately investigated and resolved.

Open Access Statement: This is an Open Access article distributed in accordance with the Creative Commons Attribution-NonCommercial-NoDerivs 4.0 International License (CC BY-NC-ND 4.0), which permits the noncommercial replication and distribution of the article with the strict proviso that no changes or edits are made and the original work is properly cited (including links to both the formal publication through the relevant DOI and the license). See: https://creativecommons.org/licenses/by-nc-nd/4.0/.

\section{References}

1. Reeb J, Olland A, Massard G, et al. Extracorporeal life support in thoracic surgery. Eur J Cardiothorac Surg 2018;53:489-94.
2. Rinieri P, Peillon C, Bessou JP, et al. National review of extracorporeal membrane oxygenation as respiratory support in thoracic surgery excluding lung transplantation. Eur J Cardiothorac Surg 2015;47:87-94.

3. Biscotti M, Yang J, Sonett J, et al. Comparison of extracorporeal membrane oxygenation versus cardiopulmonary bypass for long transplantation. J Thorac Cardiovasc Surg 2014;148:2410-5.

4. Del Sorbo L, Pisani L, Filippini C, et al. Extracorporeal $\mathrm{CO} 2$ removal in hypercapnic patients at risk of noninvasive ventilation failure: a matched cohort study with historical control. Crit Care Med 2015;120-7.

5. Lang G, Ghanim B, Hötzenecker K, et al. Extracorporeal membrane oxygenation support for complex tracheobronchial procedures $\uparrow$. Eur J Cardiothorac Surg 2015;47:250-5; discussion 256.

6. Bedeir K, Seethala R, Kelly E. Extracorporeal life support in trauma: worth the risk? A systematic review of published series. J Trauma Acute Care Surg 2017;82:400-6.

7. Malekan R, Sauders P, Yu CJ, et al. Peripheral extracorporeal membrane oxygenation: comprehensive therapy for high-risk massive pulmonary embolism. Ann Thorac Surg 2012;94:104-8.

8. Kim SH, Song S, Kim YD, et al. Outcomes of Extracorporeal Life Support During Surgery for the Critical Airway Stenosis. ASAIO J 2017;63:99-103.

9. Peek GJ, Mugford M, Tiruvoipati R, et al. Efficacy and economic assessment of conventional ventilatory support versus extracorporeal membrane oxygenation for severe adult respiratory failure (CESAR): a multicentre randomised controlled trial. Lancet 2009;374:1351-63.

10. Reeb J, Olland A, Pottecher J, et al. Extracorporeal membrane oxygenation for acute respiratory distress syndrome after pneumonectomy. Ann Thorac Surg 2017;103:881-9.

11. Nardi P, Pellegrino A, Pugliese M, et al. Cardiac surgery with extracorporeal circulation and concomitant malignancy: early and long-term results. J Cardiovasc Med (Hagerstown) 2016;17:152-9.

12. Zhang S, Tan D, Wu W, et al. Extracorporeal membrane oxygenation (ECMO) assisted mediastinal tumor resection and superior vena cava replacement are safe and feasible. Thorac Cancer 2019;10:1846-51.

13. Jones-Akhtarekhavari J, Tribble TA, Zwischenberger JB. Developing an extracorporeal membrane oxygenation program. Crit Care Clin 2017;33:767-75. 
14. Dalia AA, Ortoleva J, Fiedler A, et al. Extracorporeal Membrane Oxygenation Is a Team Sport: Institutional Survival Benefits of a Formalized ECMO Team. J Cardiothorac Vasc Anesth 2019;33:902-7.

doi: 10.21037/ccts-2020-mec-06

Cite this article as: Dell'Amore A, Asadi N. Mechanical cardiorespiratory supports in general thoracic surgeon. Curr Chall Thorac Surg 2021;3:2.
15. Brum R, Rajani R, Gelandt E, et al. Simulation training for extracorporeal membrane oxygenation. Ann Card Anaesth 2015;18:185-90. 